\title{
Phytochemical Properties and Staining Ability of Red Onion (Allium cepa) Extract on Histological Sections
}

Sunday Ewaoche Itodo*, Steve Oyero, EU Umeh, Amodu Ben and Musa Dauda Etubi

Department of Histopathology and Cytology, Jos University Teaching Hospital, Jos Plataeu State, Nigeria

*Corresponding author: Sunday Ewaoche Itodo, Department of Histopathology and Cytology, Jos University Teaching Hospital, Jos Plataeu State, Nigeria, Tel: 234 8029869531; E-mail: itodo_4real@yahoo.com

Rec date: Jun 26, 2014, Acc date: Aug 26, 2014, Pub date: Aug 28, 2014

Copyright: (C) 2014 Itodo SE, et al. This is an open-access article distributed under the terms of the Creative Commons Attribution License, which permits unrestricted use, distribution, and reproduction in any medium, provided the original author and source are credited.

\begin{abstract}
The staining ability of Allium cepa (red onion) skin extract on tissue sections was determined. The dried red onion

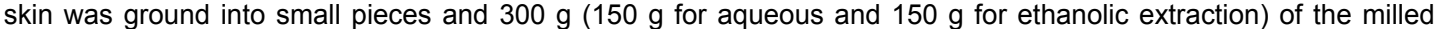
dried red onion skin was used for extraction. Dark red-pigmented granules were obtained. The aqueous and ethanolic extract of mordanted (Potassium aluminum alum and ferric chloride), non-mordanted and acidified solution prepared from the extract were used to stain tissue sections. Cytoplasm of cells and connective tissues were remarkably stained in shades of redish to yellowish brown colours. Preliminary phytochemical screening of these extracts reveals that it contained alkaloid steroid ring, saponin, Tannin, Flavonoid, Cardiac glycoside and anthraquinone. The presence of pigments, saponin, tannin, contributed to the staining ability of the extract.
\end{abstract}

Keywords: Allium cepa; Anthraquinone; Mordant; Phytochemical; Cytoplasm

\section{Introduction}

In histology, stains are substances or biological dyes, which colour tissues in order to aid optical differentiation of tissue components [1]. Dyes are coloured substance which impact colours to material such as textiles, cosmetics, foods, drugs, rubbers, plastics, hair, fur, and tissues.

There are two types of dyes, natural dyes and synthetic dye [2]. Until the middle 19th century basically all dyes were natural products extracted in most cases from plants and animals. The dyes derived from plant e.g. haematoxylin from mexican tree (Heamatoxylon campechianum), the dye derived from insect e.g. carmine from body of a female insect (Dactilopius cacti); orcein dye was derived from crocus sativus. [3].

Synthetic dyes are a large group of organic compound derived from benzene $\left(\mathrm{C}_{6} \mathrm{H}_{6}\right)$, which consists of six carbon and hydrogen atoms. Synthetic dyes are sometimes referred to as "coal tar" since they manufactured from substance which were in the past only obtained from coal tar [4].

In Africa particularly in Nigeria, there are numbers of natural dye plants which are capable of cultivation, just as we have cultivated dye plants in the United Kingdom. Recent studies have given useful result in of such abundant dye plant use as histological stains for some tissue components [5]. This is considering the huge amount of foreign exchange and processes involved in obtaining suitable synthetic dye for histological purpose, and also their attendance disadvantages. Synthetic dyes are very efficient but their application are limited due to their harzard to human and animal health [5]. This has resulted in the withdrawal of some dyes as their harzards become recognized [6].

With the wide concern favouring the use of ecofriendly and biodegradable materials, the use of natural dyes once again gain interest, [7,8]. Most developing countries can no longer afford the increasing cost of synthetic dyes. Therefore greater attention and effort is now channeled towards the use of natural occurring dye from plants which is less expensive than costly synthetic dyes.

Among numerous uses of onion, the dry onion skins were used for dyeing in classical Greece, in Persia and the Middle East, and by primitive tribes of Africa. In central Europe it was used as a dye for Easter eggs, linen, wool and especially cotton.

Dry papery skins of onion were known to be used as a natural dye in textile industry and colouring egg. Dry onion skins may be used to make plant- based dye for staining eggs or cloth [9].

This prompt an interest in this research work that explore the histological staining abilities of the dye extract of Allium cepa (red onion).

\section{Aims and Objective}

To evaluate the effect of the extract as a biological dye.

To experiment the effect of various Laboratory conditions on the staining properties of this plant extract.

\section{Methodology}

\section{Sources of red onion skin and extraction}

The papery dry skin of the red onion was obtained from Bukuru market in plateau state, Nigeria. The dried skin was oven-dried at $40^{\circ} \mathrm{C}$ and ground into small pieces. $150 \mathrm{~g}$ of the ground dried onion skin was extracted with 1 liter of hot water and another $150 \mathrm{~g}$ with 1litre of $\mathrm{n} 70 \%$ alcohol respectively.

Hot water extraction: A measured quantity (150 g) of the ground onion skin was dissolved in hot water, mixed by shaking vigorously. This was allowed standing for lhour, and then filtered to obtain the 
Page 2 of 4

coloured extract. The filtrate obtained was oven-dried to get rid of the residual water. Fourteen $(14 \mathrm{~g})$ of the dark red extract was obtained.

Using alcohol as solvent: One hundred and fifty $(150 \mathrm{~g})$ of ground onion skin was dissolved in one litre (1L) of $70 \%$ alcohol (ethanol). This was allowed standing for 48 hours. The extract was then filtered to obtain coloured extract. The filtrate was oven-dried to get rid of the residual water. $10.24 \mathrm{~g}$ of the dark -red dry extract was obtained.

\section{Preliminary phytochemical screening}

The extract of the red onion skin was screened to determine the presence of the following metabolites through the preliminary phytochemical screening. The following active constituent and metabolites were tested for:

- Alkaloid

- Flavonoid

- Tannin

- Cardiac glycosides

- Anthroquinone

- Saponin

- Anthracyanosides

\section{Alkaloids}

The extract $(0.5 \mathrm{~g})$ was stirred with $5 \mathrm{ml}$ of dilute $\mathrm{HCl}$ on a stream bath; $1 \mathrm{ml}$ of the filtrate was treated with few drops of Mayers and a second $1 \mathrm{ml}$ portion was treated similarly with dragendoff s reagent and finally another $1 \mathrm{ml}$ portion with wagner's reagent (Table 1 ).

\begin{tabular}{|l|l|l|}
\hline Test & Observation & Inference \\
\hline $\begin{array}{l}\text { Alkaloid } \\
\text { (i) } 1 \mathrm{ml} \text { of extract }+ \text { few } \\
\text { drops of Drangendoff's } \\
\text { reagent }\end{array}$ & Yellowish brown colour & Alkaloid inferred \\
\hline $\begin{array}{l}\text { (ii) } 1 \mathrm{ml} \text { of extract }+ \text { few } \\
\text { drops of Mayers reagent }\end{array}$ & Yellowish colour seen & Alkaloid inferred \\
\hline $\begin{array}{l}\text { (iii)1 ml of extract + } \\
\text { Wagner's reagent }\end{array}$ & Dark turbid brown & Alkaloid inferred \\
\hline
\end{tabular}

Table 1: Biochemical tests for Alkaloids presence

\section{Tannins}

Each portion of alcohol and water extract $(5 \mathrm{~g})$ was stirred with 10 $\mathrm{ml}$ of alcohol and distilled water respectively. They were filtered and ferric chloride reagent was added to filtrates and $1 \mathrm{ml}$ portion of the extract was treated with bromine water (Table 2).

\begin{tabular}{|l|l|l|}
\hline Test & Observation & Inference \\
\hline $\begin{array}{l}\text { (i) } 1 \mathrm{ml} \text { of extract }+1 \mathrm{ml} \\
\text { ferric chloride }\end{array}$ & Blue black precipitate & Catecol tannin present \\
\hline $\begin{array}{l}\text { (ii) of extract }+ \text { bromine } \\
\text { water }\end{array}$ & Brownish red turbid & Condensing tannins \\
\hline
\end{tabular}

Table 2: Biochemical tests for Tannins presence

\section{Flavonoid}

(i) Lead Acetate Test: $0.2 \mathrm{ml}$ of the extract was added to $0.2 \mathrm{ml}$ of $10 \%$ Lead acetate, the mixture was gently shaken to avoid emulsion.

(ii) Ferric Chloride Test: $0.2 \mathrm{ml}$ of $10 \%$ ferric chloride was added to the extract. The mixture was shaken together to observe colour.

(iii) Sodium Hydroxide Test: $0.2 \mathrm{ml}$ of dilute $\mathrm{NaOH}$ was added to $0.2 \mathrm{ml}$ of the extract shaken gently (Table 3 ).

\begin{tabular}{|l|l|l|}
\hline Test & Observation & Inference \\
\hline $\begin{array}{l}\text { (i) Lead acetate on } \\
\text { extract }\end{array}$ & Dirty brownish precipitate & Flavonoid present \\
\hline (ii) ferric chloride test & Wooly brownish colour & Flavonoid present \\
\hline $\begin{array}{l}\text { (iii) Sodium hydroxide } \\
\text { test }\end{array}$ & $\begin{array}{l}\text { Golden yellow precipitate } \\
\text { obtained }\end{array}$ & Flavonoid present \\
\hline
\end{tabular}

Table 3: Biochemical tests for Flavonoids presence

\section{Cardiac glycoside}

- Kedde's Test: $1 \mathrm{ml}$ of $8 \%$ solution of the extract was mixed with $1 \mathrm{ml}$ of $2 \%$ solution of 3,5 dinitrobenzoic acid in methanol and 1 $\mathrm{ml}$ of $5.7 \%$ aqueous sodium hydroxide

- Liebermann-burchard Test: The onion skin extract (0.5) was dissolved in $2 \mathrm{ml}$ of acetic anhydride and cooled well in Ice.; concentrated sulphuric acid was carefully added.

- Salkwoski's Test

- $0.5 \mathrm{~g}$ of the red onion skin extract was dissolved in $2 \mathrm{ml}$ of chloroform, concentrated sulphuric acid was carefully added to form lower layer.

- Keller Killiani's Test: The extract of the red onion skin $(0.5 \mathrm{~g})$ was dissolved in $2 \mathrm{ml}$ of glacial acetic acid containing one drop (1 drop) of ferric chloride solution. This was under-layered with concentrated sulphuric acid (Table 4).

\begin{tabular}{|l|l|l|}
\hline Test & Observation & Inference \\
\hline Kedde's Test & Brownish precipitate & Canclenolide \\
\hline (ii) Lieberman's Test & Deep greenish blue & Steroid nuclei inferred \\
\hline (iii) Salowiski's Test & $\begin{array}{l}\text { Reddish brown colour } \\
\text { at interface }\end{array}$ & $\begin{array}{l}\text { Deoxysugar, } \\
\text { characteristics } \\
\text { cardenolide }\end{array}$ \\
\hline
\end{tabular}

Table 4: Biochemical tests for Flavonoids presence

\section{Anthraquinone glycosides}

These occurred in both free and bound form

(i) Free Anthraquinone: The extract 0.1 was dissolved with $10 \mathrm{ml}$ hot water for aqueous extract and $10 \mathrm{ml}$ of alcohol extract, both were put in water bath to steam for 5 minutes, the solution were filtered hot, the filtrate were extracted with chloroform layer was taken off. This layer was washed with $5 \mathrm{ml}$ of water and was shaken with $5 \mathrm{ml}$ ammonia solution.

\section{(ii) Bound Anthraquinone}

A second set of the mixture was prepared with $0.1 \mathrm{~g}$ of the extract with $10 \mathrm{ml}$ of ferric chloride solution and $5 \mathrm{ml}$ hydrochloric acid. The 
Page 3 of 4

sample was hydrolysed by heating on water bath for 10 minutes, filtered hot and treated as with free anthraquinone (Table 5).

\begin{tabular}{|l|l|l|}
\hline Test & Observation & Inference \\
\hline $\begin{array}{l}\text { Free anthraquinone } \\
\text { Bontrager's test }\end{array}$ & $\begin{array}{l}\text { Presence of red colour in } \\
\text { ammonia upper phase. }\end{array}$ & $\begin{array}{l}\text { Free anthraquinone } \\
\text { present }\end{array}$ \\
\hline
\end{tabular}

Table 5: Biochemical tests for Anthraquinone Glycosides presence

\section{Saponins}

The ability of saponin to produce frothing in aqueous solution and to haemolyse red blood cells was used as screening.

(i) Frothing Test: A little portion of the extract was shaken with water in a test tube.

(ii) Haemolysed Test: Exactly 0.2 g red onion skin extract was dissolved in $10 \mathrm{ml}$ of warm water and filtered, remaining the filtrate. 2 $\mathrm{ml}$ of $1.8 \%$ sodium chloride $(\mathrm{NaCl})$ solution was put into two test tubes. To one of these $2 \mathrm{ml}$ distilled water was added. The concentration of sodium chloride in each test tube was isotonic with blood serum. Five drops of blood were added to each tube and the tubes were inverted gently to mix the contents

\section{Preparation of staining solutions and staining methods}

From the dry extract of the red onion skin obtained by aqueous and alcoholic extraction was prepared various solution thus:

Aqueous extract: Eight- $8 \mathrm{~g}$ ( $2 \mathrm{~g}$ each) of dry aqueous extract was dissolved in $100 \mathrm{ml}$ distilled water in four various bottles. One of the solutions was saturated with potassium aluminum alum, and another with ferric chloride as mordants. To the third container of the extract was added $1 \%$ acetic acid. The fourth (4th) solution of the aqueous extract was used without additional substance.

Alcoholic extract: Two $(2 \mathrm{~g})$ of the dried alcoholic extract were dissolved in four bottles containing $100 \mathrm{ml}$ of $70 \%$ alcohol. Two of the solution in the bottle were saturated with mordant (Potassium aluminum alum and Ferric chloride) separately, the third bottle was added $1 \%$ acetic acid, and the fourth $\left(4^{\text {th }}\right)$ bottle contain only $2 \mathrm{~g}$ of the extract dissolved in $70 \%$ alcohol.

Identification of hydrogen ion concentration of the various solution of the red onion extract: The $\mathrm{pH}$ of the varying mixture of red onion skin extract was determined using $\mathrm{PH}$ meter and the results obtained were shown below (Table 6):

\begin{tabular}{|l|l|}
\hline Mixture of Extract & $\mathrm{pH}$-value \\
\hline Aqueous solution of the onion extracts & 3.11 \\
\hline $\begin{array}{l}\text { Aqueous extract solution with } \\
\text { potassium alum }\end{array}$ & 1.51 \\
\hline $\begin{array}{l}\text { Aqueous extract solution with ferric } \\
\text { chloride }\end{array}$ & 1.26 \\
\hline $\begin{array}{l}\text { Aqueous extract solution with 1\% } \\
\text { acetic acid }\end{array}$ & 2.51 \\
\hline $\begin{array}{l}\text { Alcoholic (ethanol) in 70\% alcohol } \\
\text { 70\% alcoholic extract solution with } \\
\text { potassium alum }\end{array}$ & 1.94 \\
\hline
\end{tabular}

\begin{tabular}{|l|l|}
\hline $\begin{array}{l}70 \% \text { alcoholic extract solution with } \\
\text { ferric chloride }\end{array}$ & 0.01 \\
\hline $\begin{array}{l}70 \% \text { alcoholic extract solution with } 1 \% \\
\text { acetic acid }\end{array}$ & 3.25 \\
\hline
\end{tabular}

Table 6: Determination of $\mathrm{pH}$ of the varying mixture of red onion skin extract using $\mathrm{PH}$ meter

\section{Preparation of sections}

Tissue of kidney, liver, and testes obtained at postmortem were processed using the standard paraffin wax processing schedule. Sections of $5 \mu \mathrm{m}$ thickness were cut from these block using rotary microtome, floated out in warm water bath, picked onto microscope glass slides and allowed to fix on the hot plate. Sections were exposed to the extracts solutions at various concentration and timing.

\section{Staining procedure}

All sections were taken down to water and then given various treatment thus, The sections were stained with various solution prepared from aqueous and alcoholic solution (Aqueous solution of the onion extract, Aqueous extract solution with potassium alum, Aqueous extract solution with ferric chloride, Aqueous extract solution with $1 \%$ acetic acid, Alcoholic extract (ethanol) in $70 \%$ alcohol, 70\% alcoholic extract solution with potassium alum, 70\% alcoholic extract solution with ferric chloride, $70 \%$ alcoholic extract solution with $1 \%$ acetic acid) for 30 minutes, while other sets of sections were treated with warm prepared solution for 10 minutes. The sections were rinsed, dehydrated, cleared and mount with DPX. Each slide was viewed under X10 and X40 objectives for the characteristics of the structures with the staining solution.

\section{Results}

Among numerous uses of onion parts, the dry onion skin were used for dyeing in classical Greece, in Persia and the Middle East, and by primitive tribes in Africa. In central Europe they were used as a dye for Easter egg linen, wool and especially cotton. The papery skin of onion produces dye when boiled in water and the filteration was used as dye solution.

Complete extraction of red onion skin extract gave a dark reddish colour. Addition of mordants changed the colour of the extract to greenish red and black respectively. With ferric chloride as mordant the extract turned black, while the mordanted extract with potassium aluminium alum turned greenish red.

Various solutions prepared from the extract stained sections of Testes, Liver and Kidney shades of reddish brown to yellowish brown in 20 minutes at room temperature, while the warm solutions stained sections 5 minutes, this is central to the increased permeability the heat conferred on the sections. Generally the cytoplasm of the tissue sections was stained along with the nucleus with a little optical differentiation; but the staining ability of the extract was found to be remarkably impacted on the connective tissues with ferric chloride mordanted solution showing the best staining ability. 
The $\mathrm{pH}$ of various prepared solutions showed that the onion skin extract solution were highly acidic hence having the cytoplasmic staining ability rather than the nuclei, which can be faintly identified.

The ability of the solutions as counterstain after haematoxylin as primary stain showed that the dye solution of red onion stained cytoplasm and connective tissues well.

\section{Discussion}

During staining, dye molecules in stain appear as a certain color and attached to a specific site or cellular structure. Combination of stains may be necessary to affect certain tissue demonstrated. This goes to show that a dye must ionize in solution to produce colored cations and anions which are capable of uniting with tissue components to form colored compounds [2]. Red onion skin extract with aqueous and alcoholic extraction in this research has shown good staining quality that also perishes after a given time.

Many used in histochemistry including haematoxylin which is first oxidized to haematin required an additional intermediate metallic substances known as a mordant before satisfactory combination with tissue takes place; but exposure of the onion skin extract to sunlight and air for over one month (for oxidation) with the addition of mordants has no positive effect or added advantage in the staining ability of the extract. This agrees with a recent work by Avwioro et al. [5] on Pterocarpus osun as a histological stain for collagen fibres, indicating that the use of potassium aluminium alum as a mordant had no significant effects on the staining qualities of Pterocarpus osun.

Hoffman and Bauknecht [9] had earlier observed the effect of ionic strength and $\mathrm{pH}$ of staining reaction. In this experiment, the ferric chloride mordanted alcoholic extract with the lowest $\mathrm{pH}$ value $(0.1)$ seems to have little more staining impact on the connective tissue; but the differences in the $\mathrm{pH}$ of various solution did not show significant staining differences.
A slight increase in temperature of the red onion skin extract showed a significant reduction in the staining time to about 5 minutes with a deeper color impactation. The use of red onion skin extract as a counterstain when haematoxylin was used as primary stain showed that the dye extract was a good counterstain as it stained connective tissues and cytoplasm well. It may therefore be concluded that Allium cepa (red onion) skin extract is a promising histological stain that can serve as a useful stain for histopathological diagnosis.

\section{References}

1. Culling CFA (1974); Handbook of Histological and Histochemical techniques. 3rd ed. Butherworths Co. Ltd London.

2. Carleton HM, Drury RAB, Wallington EA, Cameron R (1976) Histology Technique, (4th edn), Oxford University Press Lond.

3. Avvwioro OG (2002) Histochemistry and tissue Pathology claverianum press Ibadan Nigeria. 134- 213

4. Banerjee A, Mukherjee AK (1981) Chemical aspects of santalin as a histological stain. Stain Technol 56: 83-85.

5. Avwioro OG, Aloamaka PC, Ojianya NU, Oduola T, Ekpo EO (2005) Extract of Pterocarpus osun as a histological stain for collagen fibres. Af J Biotech 4: 460-464.

6. Bhuyan R, Saikia CN (2005) Isolation of colour components from native dye-bearing plants in northeastern India. Bioresour Technol 96: 363-372.

7. Eom S, Shin D, and Yoon K (2001) Improving the Dye Ability of Natural Colourants on Cotton by Cationization. Ind. J. Fibre Text. Res. 26: $425-431$

8. Garg A, Shenda S, Gupta KC (1991) Effect of Mordant on Colour of Natural Dye Extracted from Tissue Flowers (Butea mongsperma). Colourage 38: 50-53.

9. Hoffmann EM, Bauknecht N (1999) A dye binding assay for the quantification of soluble and cell-bound acidic polysaccharides produced by red algae. Anal Biochem 267: 245-251. 